Works of the Faculty of Forestry

University of Sarajevo

No. 2, 2018 (41-53)

UDK 556.115:574.587(282.249 Neretva)

\title{
A BIOLOGICAL WATER QUALITY ASSESSMENT BASED ON PHYTOBENTHOS AND MACROINVERTEBRATES AT THREE STATIONS ON THE RIVER NERETVA
}

\section{Biološka procjena kvalitete vode na tri postaje na rijeci Neretvi temeljena na zajednicama fitobentosa i makrozoobentosa}

Anita Dedić ${ }^{1}$, Tanja Galić ${ }^{2}$, Svjetlana Stanić-Koštroman ${ }^{1}$, Dragan Škobić ${ }^{1}$, Anđelka Lasić ${ }^{1}$ and Dubravka Hafner ${ }^{3}$

\begin{abstract}
This paper presents the research results of benthos community (phytobenthos and macroinvertebrates) on three locations of the Neretva River: Glavatičevo, Žitomislići and Višići. According to typology of rivers, the site Glavatičevo belongs undertype 10a, while sites Žitomislići and Višići are undertype JIVT (heavily modified water bodies). Research of the benthos community has been done in December 2016 with the simultaneous monitoring chemical parameters of water. All research states showed a great number and a high diversity of benthic taxa, although sampling was spent in December. The saprobic values of benthos community at the site Glavatičevo indicates to oligosaprobic level, the water unloaded with organic substances. The site Žitomislići points to oligo/betamesosaprobic level, the water a bit loaded with organic substances. The site Višići according to phytobenthos demonstrates to oligo/betamesosaprobic level, while according to benthic macroinvertebrates point to betamesosaprobic level (the water loaded with organic substances). Based on saprobic values and chemical parameters of water in keeping with The decision on the characterization of the surface and underground water, reference conditions and parameters for the detection of water state and water monitoring (Official newspapers $\mathrm{FBiH}$, No. 1/14), a maximum ecological potential has been registered on sites Žitomislići and Višići, while a high ecological status has been registered on the site Glavatičevo.
\end{abstract}

Key words: phytobenthos, macrozoobenthos, ecological status, ecological potential

\section{INTRODUCTION - Uvod}

Biodiversity of freshwater ecosystems are under increasing influence of negative anthropogenic activity. Consequently, there are more visible changes in biota and biological processes in water (NORRIS and BARBOUR, 2009). The traditional water quality assessment has been based exclusively on measuring physical and chemical parameters of water, but later this was not enough and biological parameters

\footnotetext{
${ }^{1}$ University of Mostar, Faculty od Science and Education, Bosnia and Herzegovina

${ }^{2}$ Kočerin, b.b., Široki Brijeg, Bosnia and Herzegovina

${ }^{3}$ Bartulovići 4, HR-20357, Croatia
} 
were included. Organisms community in freshwater ecosystems are sensitive indicators of water status, because they integrate and maintain the influence of various environmental factors, various types of contamination, degradation, fragmentation of habitats and etc. (NORRIS and BARBOUR, 2009).

According to The Water Framework Directive (2000/60/EC), the most important part of the EU legislation on the water, all the EU member states are required to make an assessment of the status of water bodies as well as their classification. Goals of water protection and management in FB\&H are defined by the Water Act FB\&H (Official Newspaper FBiH, No. 70/06) and Water management strategy FB\&H (adopted by The House of Representatives and The House of Peoples of the Bosnia and Herzegovina Parliament 2010, respectively 2011 with plan valid until 2022).

The Water Framework Directive is the most important part of the EU legislation on water. It designed to improve and integrate the way water bodies across Europe are managed, ensure sustainable management, prevent further destruction of the surface and groundwater and ensure the least good status of all water bodies (HERCEG, 2013). According to WFD the ecological status of surface water involves the analysis of biological elements of water quality, basic chemical and physical and-chemical elements supporting the biological elements and hydromorphological elements. If the status of the biological and physical and-chemical element is assessed as good, and of the hydromorphological as moderate, total ecological status will be estimated as moderate. The ecological status is esteemed on the basis of the worst rated component.

Phytobenthos represents the community composition of algae, cyanobacteria and heterotrophic microorganisms, who cover free object surface within the water (PLENKOVIĆ-MORAJ et al., 2009). Benefits of phytobenthos as indicators of the ecological status and monitoring are: the great taxonomic diversity, short generation time and a quick response to stress, respectively to changes in ecological conditions. Phytobenthos communities are the first to react to the change that has occurred in the water, respectively they behave as early detectors of the problem.

Benthic macroinvertebrates, especially aquatic insects, represent a choice group of organisms used in the biological monitoring programs. Macroinvertebrates within the same system may be residents for several months to multiple years, depending on the lifespan of the particular organism. Macroinvertebrate communities therefore reside in an aquatic system long enough to reflect the chronic effects of pollutants, and yet short enough to respond to relatively acute changes in water quality. Thus, because of the limited mobility of macroinvertebrates and their relative inability to move away from adverse conditions, the location of the chronic sources of pollution often can be pinpointed by comparing communities of these organisms. Benthic macroinvertebrates are used as a bioindicators for environmental stress in aquatic ecosystems at different levels, including morphological deformities.

Similar researches have been made earlier, as evidenced by published papers (JERKOVIĆ, 1976; BLAGOJEVIĆ, 1976; MARINKOVIĆ-GOSPODNETIĆ, 1978; BLAGOJEVIĆ and HAFNER, 1981, 1983; BLAGOJEVIĆ et al., 1986). This papers mostly have been referred to assessment of the water quality. Also, published data about 
benthos community points to the specificity of the area as well as the high degree of endemism (KAĆANSKI, 1978; MARINKOVIĆ-GOSPODNETIĆ, 1978).

In recent times, more precisely since establishing a water agency for the Adriatic Sea, regular biomonitoring programs are being conveyed within the framework of monitoring the state of the Neretva River.

This thesis presents assessment of ecological status on three locations of Neretva river using phytobenthos and macroinvertebrates community and chemical elements of water.

\section{MATHERIAL AND METHODS - Materijal i metode}

Research of benthos was made in December 2016. Phytobenthos, macroinvertebrates were sampled and chemical parameters of water were measured. The assessment of the ecological status has been made according to the applicable legal regulations, respectively the decision on the characterization of the surface and underground water, reference conditions and parameters for the detection of water state and water monitoring (Official newspapers $\mathrm{FBiH}$, No. 1/14).

Chemical parameters were measured by an ecological probe type WTW MultiParameter Instruments. $\mathrm{pH}$ values were measured by the $\mathrm{pH}$-meter, model HANNA HI 98127, conductivity was measured by WTW field meter, model Cond 3110 , and dissolved oxygen was measured by WTW field meter, model Ox 3205. Of chemical analyses the content of total carbon (TOC) and the content of total organs of carbon (NPOC) were determined by TOC analyzer. Samples for analyses concentrations of ammonium, nitrate and phosphates also were sampled. They were measured in the laboratory using a UV-visible spectrophotometer. Chemical analysis was done in Institute of Public Health FB\&H Mostar.

Phytobenthos samples were taken according to European Standard EN 13946 (2016). Phytobenthos were sampled from the surface of the rocks by scraping with a scalpel and a toothbrush. The samples of phytobenthos (diatoms and the other algae) were fixed in $4 \%$ formaldehyde at the site. Diatoms were determined from the permanent preparations that were made after the chemical processing of materials by HUSTEDT, (1930). Algae were determined using ZEISS light microscope (Axio Imager A2). The diatoms were identified at a high magnification (100X) while using immersion oil, and the other algae were identified under different magnification (4x, 10x and 40x). Counting of taxa was made in arbitrary transcriptions counting 400 frustules on a light microscope with the contrast (DIC) on magnification 1000x. The indetification of the species was made using the keys: GOLERBACH et al. (1953), HINDAK et al. (1978), HUSTEDT, (1927 - 1966, 1930), KOMAREK and ANAGNOSTIDIS (1999), LENZENWEGER, (1996), ZABELINA et al. (1951), WEST, (1905), KRAMMER and LANGE-BERTALOT (1986 - 1991), KRAMMER, (2000 - 2003), LANGE-BERTALOT (2001, 2002). 
Based on the qualitative and quantitative composition of phytobenthos, the saprobiological state of the investigated stations was determined. The indicator values of taxa were defined by WEGL, (1983) and the saprobity index was estimated according to PANTLE-BUCK, (1955) and ZELINKA-MARVAN, (1961). The relative abundance was expressed by number 1,3 and 5 (1-single, 3 -usual, 5 -dominant). Water quality category was given by LIEBMANN, (1962) (Table 1).

The samples macrozoobenthos were sampled by AQEM method and multihabitat sampling sheme. It covers the collection of material from all microstation of the defined station, which is represented by at least 5\% coverage (totally 20 subsamples). In this study Surber's net a surface area of $0.1 \mathrm{~m}^{2}$ was used and a grinder mill with a diameter of $150 \mu \mathrm{m}$. The samples of macrozoobenthos were fixed in $80 \% \mathrm{EtOH}$ at the site. The qualitative and quantitative analysis and determination of materials were made in the scientific research laboratory "Ruđer Bošković" Faculty of Science and Education at the University of Mostar. The determination of species was made using the keys for certain groups of macroinvertebrates: ASKEW, (1988), BELIFORE, (1983), CARCHINI, (1983), CONSIGLIO, (1980), ELLIOTT et al. (1988), ENGBLOM, (1996), HICKIN, (1967), NILSSON, (1996), PELEGER, (1999), WARINGER and GRAF (2011), WATSON and DALLWITZ (2005) under the sterezoom microscope Olympus SZX10. The Pantle-Buck saprobic index was used for assessing the ecological status and burden of organic pollution of aquatic ecosystems. Saprobic value of the taxa was defined by MOOG, (2002) and data base (freshwaterecology.com). The relative abundance was defined by RUSSEV, (1993). The water quality category was given by LIEBMANN, (1962) (Table 1).

Table 1 . The water quality category according to the saprobic index

Tablica 1. Kategorija kvalitete vode prema saprobnom indeksu

\begin{tabular}{|c|c|c|}
\hline SAPROBITY DEGREE & INDEX SAPROBITY & $\begin{array}{c}\text { DESCRIPTION OF A } \\
\text { WATER BIOTOPE }\end{array}$ \\
\hline Oligosaprobic & $1.00-1.50$ & $\begin{array}{c}\text { Unloaded to very little } \\
\text { loaded }\end{array}$ \\
\hline Oligo to $\beta$-mesosaprobic & $1.51-1.80$ & Little loaded \\
\hline$\beta$-mesosaprobic & $1.81-2.30$ & Moderately loaded \\
\hline$\beta$ to $\alpha$-mesosaprobic & $2.31-2.70$ & Medium loaded \\
\hline$\alpha$-mesosaprobic & $2.71-3.20$ & Loaded loaded \\
\hline$\alpha$ to polisaprobic & $3.21-3.50$ & Very much loaded \\
\hline Polisaprobic & $3.51-4.00$ &
\end{tabular}

The study area: The Neretva River is the largest river of the Adriatic catchment area. It flows $203 \mathrm{~km}$ through Bosnia and Herzegovina, and the last $22 \mathrm{~km}$ through the Croatia. River water flows mainly through limestone in accordance with the hydrogeological characteristics of the karst flow. Climate characteristics in the river basin vary with the distance from the sea. The climate is Mediterranean in the lowland 
area close to the sea, while the middle part has a continental climate and higher areas have a mountainous climate. The average rainfall is $1.6501 / \mathrm{m}^{2}$, and varies between 1.500 and $18001 / \mathrm{m}^{2}$. Temperatures range between -29 and $+43{ }^{\circ} \mathrm{C}$, and the annual evapo-transpiration is $500-900 \mathrm{~mm}$.

Three investigated stations are presented in this paper (Photo 1). The first site: Glavatičevo (Photo 2) is on $358 \mathrm{~m}$ atitude. According to typology of rivers, it belongs undertype 10a (medium high mountain stream on the carbonate substrate). The second site: Žitomislići (Photo 3) is on $19 \mathrm{~m}$ atitude. According to typology of rivers, it belongs undertype JIVT (heavily modified water body). The third site: Višići (Photo 4) is on 8 $\mathrm{m}$ atitude. It belongs undertype JIVT (heavily modified water body).

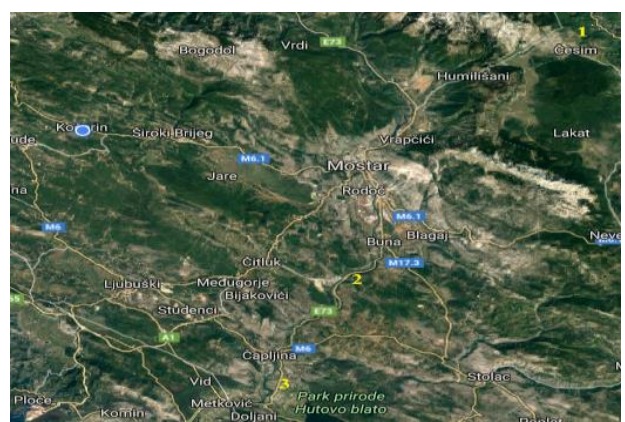

Photo 1. Research sites at Neretva River Slika 1. Područja istraživanja na rijeci Neretvi

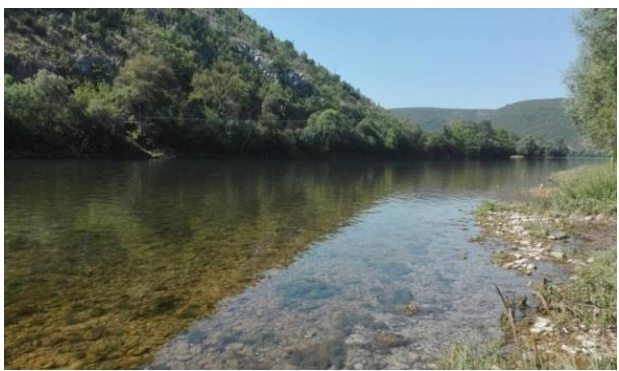

Photo 3. Neretva: Žitomislići site Slika 3. Neretva: postaja Žitomislići

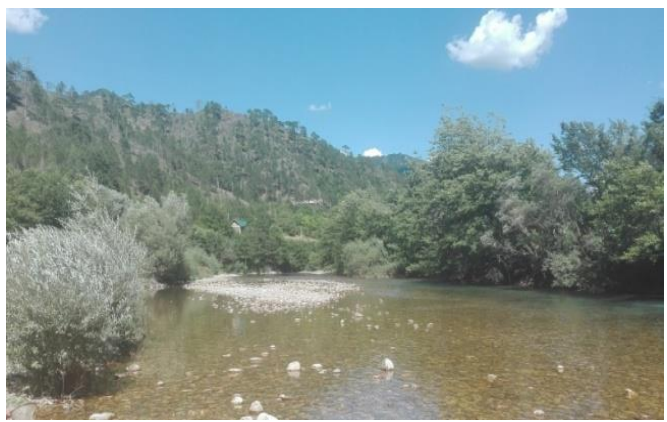

Photo 2. Neretva: Glavatičevo site Slika 2. Neretva: postaja Glavatičevo

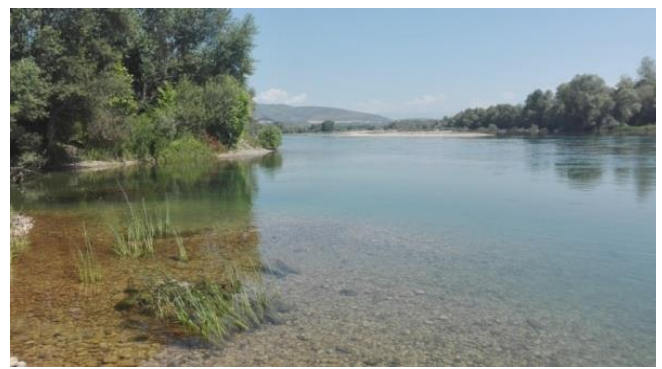

Photo 4. Neretva: Višići site Slika 4. Neretva: postaja Višići

\section{RESULTS AND DISCUSSION - Rezultati i rasprava}

The results of selected chemical parameters of water at investigated stations are shown in Table 2. 
Table 2. Values of physico-chemical and chemical parameters of water of the Neretva River at the Glavatičevo, Žitomislići and Višići sites

Tablica 2. Vrijednosti fizikalno-kemijskih i kemijskih čimbenika vode rijeke Neretve na postajama: Glavatičevo, Žitomislići $i$ Višići

\begin{tabular}{|c|c|c|c|c|c|c|c|c|c|}
\hline & 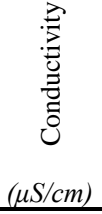 & $\mathrm{pH}$ & 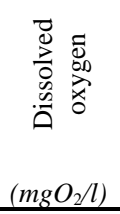 & 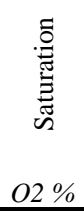 & $\frac{n}{\infty}$ & 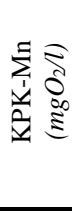 & $\begin{array}{c}\text { 夏 } \\
\text { 章 } \\
\text { 甚 } \\
(m g N / l) \\
\end{array}$ & 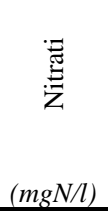 & $\begin{array}{c}\mathrm{TP} \\
(m g P / l) \\
\end{array}$ \\
\hline Glavatičevo & 284 & 8 & 13.2 & 105.6 & 0.63 & 0.64 & $<0.005$ & 0.263 & 0.007 \\
\hline Žitomislići & 380 & 7.8 & 11.59 & 96.4 & 0.67 & 0.64 & 0.01 & 0.517 & 0.012 \\
\hline Višići & 456 & 8 & 12.86 & 113.1 & 0.51 & 0.77 & 0.017 & 0.602 & 0.047 \\
\hline
\end{tabular}

All the stations showed a high oxygen value (dissolved oxygen-11.59-13.20 mg $\mathrm{L}^{-1}$ and saturation -96.4-113\%). Reason for that can be the less values of water temperature, porosity of aquifer rock and contact with groundwater with atmosphere (CANTONATI, 1998). Conductivity was ranged between 284 and $456 \mu \mathrm{S} / \mathrm{cm}$ (table 2). The measured value of electrical conductivity can assess the degree of mineralization of water and also to evaluate of the kind of water (WALTON, 1989). Our values are in agreement with values for limestone substrate (MOGNA et al., 2015). Also, our values are in agreement with values of factors for the Žitomislići and Višići sites who were presented in the paper by IVANKOVIĆ et al. (2017).

In accordance with The decision on the characterization of the surface and underground water, reference conditions and parameters for the detection of water state and water monitoring (Official newspapers $\mathrm{FBiH}$, No. 1/14), all the obtained values of chemical parameters of water at the Žitomislići and Višići sites are within the limits of maximum ecological potential, and at the Glavatičevo site are within the limits of a high ecological state.

In terms of phytobenthic communities, it was recorded a great number and high diversity of taxa. A total of 67 taxa of phytobenthos were determineted at all stations (Glavatičevo 26, Žitomislići 46 and Višići 20 taxa). The most common and the most numerous were representative from the classes of Bacillariophyceae. Species Cocconeis placentula Ehrenberg, Diatoma vulgaris Bory, Encyonema silesiacum (Bleisch) D. G. Mann, Navicula tripunctata (O. F. Müller) Bory, Rhoicosphenia abbreviata (C. Agardh) Lange-Bertalot and Ulnaria ulna (Nitzsch) Compère were registered at all stations. All presented taxa are cosmopolitan with a wide amplitude of appearances. Saprobic index for the phytobenthos at the site Glavatičevo was 1.41 , at the site Žitomislići 1.7 and at the site Višići 1.8. According to the saprobic index site Glavatičevo belongs to I category of water quality or oligosaprobic water level (the unloaded to very little loaded waters), while the Žitomislići and Višići sites belong to I-II category of water quality or oligo-betamesosaprobic water level (the litlle loaded waters). According to the research 
results conducted by TROŽIĆ-BOROVAC et al. (2013) in the period from 2005. to 2010. were determined 62 taxa at the Žitomislići site and 47 at the Višići site. The reason for their greater number of taxa is certainly the greater number of samples as well as the longer period of research. The most numerous genera in this paper: Cocconeis, Encyonema, Diatoma, Gomphonema and Navicula were recorded in the study of other authors of karst rivers (WOJTAL, 2009), NOGA et al. (2013), MOGNA et al. (2015), IVANOV et al. (2006)). According to the list of indicator types (VAM DAM et al., 1994), the most abundant taxa at the sites on the Neretva River are alkaliphilous and circumneutral species, which corresponds to the measured $\mathrm{pH}$ values.

In terms of macroinvertebrates 198 individuals of 16 taxa were dermineted at the site Glavatičevo, 346 individuals of 16 taxa at the site Žitomislići and 381 individuals of 13 taxa. The most diverse groups at all stations were insect class representatives Insecta, especially orders Trichoptera, Ephemeroptera and Plecoptera. The species Gammarus balcanicus Schäferna, 1922, was the most diverse species at the Žitomislići and Višići sites. Saprobic index at the site Glavatičevo was 1.48, at the site Žitomislići 1.58 and at the site Višići 1.89. According to the saprobic index the site Glavatičevo belongs to I category of water quality or oligosaprobic water level (the unloaded to very little loaded waters), the site Žitomislići belongs to I-II category of water quality or oligo-betamesosaprobic water level (the litlle loaded waters) and the site Višići belongs to betamesosaprobic water level (moderately loaded waters).

Comparison of the values of saprobic index for both biological parameters indicates the relative uniformity.

\section{CONCLUSION - Zaključci}

Based on the results obtained by researching the benthic communities at the three Neretva River stations we make the following conclusions:

- Data of chemical variables show good aeration, $\mathrm{pH}$ typical for carbonate bed/origin and generally oligotrophic conditions.

- According to the chemical parameters of water, the largest number of benthic taxa are alkaliphilous and circumneutral species, and they are mesosaprobic indicators.

- In the Neretva river were recorded high number and high diversity of phytobenthos and macrozoobenthos taxa.

- According to the research results, the site Glavatičevo points to the good water quality, while the Žitomislići and Višići sites evaluated to the presence of organic contamination.

- The high ecological status was assessed for the site Glavatičevo, and for the Žitomislići and Višići sites were assessed maximum ecological potential. 


\section{REFERENCES - Literatura}

ASKEW, R. R. (1988). The Dragonflies of Europe. Harley Books, Essex. pp 29.

BAUERNFEIND, E., SOLDÁN, T. (2012). The mayflies of Europe. Apollo Books. pp 781.

BELIFORE, C. (1983). Efemerotteri (Ephemeroptera). In: Ruffo, S.(ed.): Guide per il riconoscimento delle specie animali delle acque interne Italiane. Consiglio nazionale delle ricerche, Verona. pp 113.

BLAGOJEViĆ, S. (1976): Prilog poznavanju algi krških izvorišta u Bosni i Hercegovini. I. Chrysophyceae, Xanthophyceae, Bacillariophyceae. Godišnjak Biološkog instituta Univerziteta u Sarajevu. 29: 5-21.

BLAGOJEVIĆ, S., HAFNER D. (1981): Florističko-ekološka istraživanja cijanofita i algi fitobentosa i biosestona u srednjem toku rijeke Neretve i njenim pritokama. Elaborat Biološkog Instituta Univerziteta u Sarajevu.

BLAGOJEVIĆ, S., HAFNER D. (1983): Naselje cijanobakterija i algi u rijeci Neretvi. Elaborat, Biološki aspekt kvaliteta vode ekosistema rijeke Neretve. Biološki Institut Univerziteta u Sarajevu.

BLAGOJEVIĆ, S., HAFNER, D., KRIVOKAPIĆ, K., KAĆANSKI, D. (1986): Neke hidrobiološke karakteristike akumulacionih jezera na Neretvi i Trebišnjici. Prirodno - Matematički fakultet Univerziteta u Sarajevu.

BRitTAin, J. E., SALTVEiT, S. J. (1996). Plecoptera, Stoneflies. In: Nilsson, A. (ed.): Aquatic Insects of North Europe, Apollo Books, Stenstrup. 55-76.

CARCHINI, G. (1983). Odonati (Odonata). In: Ruffo, S. (ed.): Guide per il riconoscimento delle specie animali delle acque interne Italiane. Consiglio nazionale delle ricerche, Verona. pp 80.

COESEL, P.F.M. (1991). De Desmidiaceeën van Nederland Deel 4. Fam. Desmidiaceae (2) Wetensch. Meded. K.N.N.V. 202, Utrecht.

CONSiglio, C. (1980). Plecotteri (Plecoptera). In ruffo, S. (ed.): Guide per il riconoscimento delle specie animali delle acque interne Italiane. Consiglio nazionale delle ricerche, Verona. pp 68.

ELLIOTT, J.M., HUMPESCH, U.H., MACAN, T.T. (1988). Larvae of the British Ephemeroptera: a key with ecological notes, Freshwater Biological Association, Ambleside, 145 pp.

ENGBLOM, E. (1996). Ephemeroptera Mayflies. In: Nilsson, A. (ed.): Aquatic Insects of North Europe. Apollo Books, Stenstrup. 13 - 54.

EU, 2000. Directive 2000/60/EC of the European Parliament and of the Council of 23 October 2000 establishing a framework for Community action in the field of water 
policy. Official Journal of the European Coounities L 327, 22.12.2000, Luxembourg, pp. 72.

GHETTi, PF. (1986). I macroinvertebrati nell'analisi di qualitá dei corsi d'acqua. Trento: Provincia Autonoma di Trento. 169 p. Manuale di applicazione. Volume allegato agli atti del convegno "esperienze e confronti nell'applicazione degli indici biotici in corsi d'acqua italiani

GOLERBACH, M. M., KOSINSKAJA, E. K., POLJANSKI V. I. (1953): Sinzelenije vodorosli. Gos. Izd. Sovjetskaja nauka, Moskva.

HERCEG, N. (2013). Okoliš i održivi razvoj. Synopsis. Zagreb.

HiCKIN, N. E. (1967): Caddis larvae (Larvae of British Trichoptera), Hutchinsin \& Co. London, pp. 476.

HINDAK, F. (1988): Studies on the Chlorococcal Algae (Chlorophyceae). IV. Slovak Academy of Science, Bratislava.

HINDAK, F., CYRUS, Z., MARVAN, P., JAVORNICKY,P., KOMAREK, J., ETTL. H., ROSA, K., SLADEČKOVA, A., POPOVSKI,J., PUNOCHAROVA, J., LHOTSKY, O. (1978): Slatkovodne riasy, Slovenske pedagogičke nakladateljstvo, Bratislava.

HINDAK, F., MARVAN, P., ROSA, K., POPOVSKY, J., LHOTSKY, O. (1978): Sladkovodne riasy, Slovenske Pedagogicke Nakladateljstvo, Bratislava.

HUSTEDT, F. (1930): Bacillariophyta (Diatomeae). In Die Süsswasserflora Mittelleuropas vol 10. 2nd Jena, Pascher A. (ed.), Germany, G. Fischer.

IVANKOVIĆ, A., PETROVIĆ, D., IVANKOVIĆ, P. I MAJSTOROVić, J. (2017): Monitoring of Water Salinity of the Lower River Neretva (B\&H). International Journal of Energy and Environmental Science. 2: 136-143.

JERKOVIĆ, L. (1978). Dijatomeje sliva gornjeg toka rijeke Neretve. Godišnjak Biološkog instituta Univerziteta u Sarajevu.

JOHN, D.M., WHITTON, B.A., BROOK, A.J. (2002). The Freshwater Algal Flora of the British Isles: An Identification Guide to Freshwater and Terrestrial Algae. Cambridge University Press. New York. 37.

KELLY, M.G., JUGGiNS, S., BENNION, H., BURGESS, A., YALLOP, M., HIRST, H., KING, L., JAMIESON, B.J., GUTHRIE, R., RIPPEY, B. (2008): Use of diatoms for evaluating ecological status in UK freshwaters. Environment Agency, United Kingdom.

KOMÁREK, J., ANAGNOSTIDIS, K. (1999). Cyanoprokaryota 1. Teil: Chroococcales. In H. Ettl, G. Gärtner, H. Heynig, and D. Mollenhauer (Eds.). Süsswasserflora von Mitteleuropa 19/1, Gustav Fischer Verlag, Jena-Stuttgart-Lübeck-Ulm, Germany. $548 \mathrm{pp}$.

KRAMMER, K. (2000). Diatoms of Europe. Diatoms of the European Inland Waters and Comparable Habitats. Vol. 1. The genus Pinnularia. A.R.G. Gantner Verlag K.G, Ruggell. 
KRAMMER, K. (2002). Diatoms of Europe. Diatoms of the European Inland Waters and Comparable Habitats. Vol. 3. Cymbella. A.R.G. Gantner Verlag K.G, Ruggell.

KRAMMER, K. (2003). Diatoms of Europe. Diatoms of the European Inland Waters and Comparable habitats. Vol. 4. Cymbopleura, Delicata, Navicymbula, Gomphocymbellopsis, Afrocymbella. A.R.G. Gantner Verlag K.G, Ruggell.

KRAMMER, K., LANGE-BERTALOT, H. (1986). Bacillariophyceae, 1. Teil: Naviculaceae. U : Ettl, H., Gerloff, J., Heynig, H., Mollenhauer, D. (Eds): Süsswasserflora von Mitteleuropa 2/1. - G.Fischer-Verlag, Stuttgart, 876 pp.

KRAMMER, K., LANGE-BERTALOT, H. (1988). Bacillariophyceae, 2. Teil: Bacillariaceae, Epithemiaceae, Surirellaceae. U: Ettl, H., Gerloff, J., Heynig, H., Mollenhauer, D. (Eds): Süsswasserflora von Mitteleuropa 2/2. - G. Fischer-Verlag, Stuttgart.

KRAMMER, K., LANGE-BERTALOT, H. (1991a). Bacillariophyceae, 3. Teil: Centrales, Fragilariaceae, Eunotiaceae. - In: Ettl, H., Gerloff, J., Heynig, H., Mollenhauer, D. (Eds), Süsswasserflora von Mitteleuropa 2/3. - G. Fischer-Verlag, Stuttgart.

KRAMMER, K., LANGE-BERTALOT, H. (1991b). Bacillariophyceae, 4. Teil: Achnanthaceae. Kritische Ergänzungen zu Navicula (Lineolatae) und Gomphonema, Gesamtliteraturverzeichnis. U: Ettl, H., Gerloff, J., Heynig, H., Mollenhauer, D.

LANGE-BERTALOT, H. (2001). Navicula sensu stricto. 10 Genera separated from Navicula sensu lato, Frustulia. In: Diatoms of Europe: diatoms of the European inland waters and comparable habitats, Ruggell A.R.G. Gantner Verlag. K.G., pp. 526.

LANGE-BERTALOT, H. (2002). Diatoms of Europe: diatoms of the European inland waters and comparable habitats. Vol. 3, Cymbella, A. R. G. Ganter; Koeltz Scientific Books, Rugell, Königstein.

LANGE-BERTALOT, H. (2001). Navicula sensu stricto, 10 genera separated from Navicula sensu lato, Frustulia. In: Lange-Bertalot, H. (ed.), Diatoms of Europe, 2. A. R. G. Gantner Verlag K. G., Ruggell, Liechtenstein

LAZAR, J. (1960). Alge Slovenije: Seznam slatkovodnih vrst in ključ za dolčanje. SAZU, Ljubljana.

LENZENWEGER, R. (1996). Desmidiaceenflora von österreich, Teil 1, Bibliotheca Phycologica, Band 101.

LieBMAN, H. (1962). Handbuch der Frishwasser und Abwasser biologie, Vol II, 2 ndedn. Oldenbourg, Munich, pp, 588.

MARINKOVIĆ-GOSPODNETIĆ, M. (1978). Trichoptera sliva rijeke Neretve. Godišnjak Biološkog instituta Univerziteta u Sarajevu. 
MOGNA, M., CANTONATi, M., ANDREUCCI, F., ANGELİ, N., BERTA, G., MiSERERE, L. (2015): Diatom communities and vegetation of springs in the sout-western Alps. Acta Botanica Croatica. 74: 265-285.

MOOG, O. (2002). Fauna Aquatica Austriaca, Edition 2002. Wasserwirtschaftskataster Bundesministerium für Land- und Forstwirtschaft, Umwelt und Wasserwirtschaft, pp. 684 , Wien.

MORETTi, G. (1983). Tricotteri (Trichoptera). In: Ruffo, S. (ed.). Guide per il riconoscimento delle specie animali delle acque interne Italiane. Consiglio nazionale delle ricerche, Verona. 156 str.

MÜLLER-LIEBANAU, I. (1969). Revision der europäischen Arten der Gattung Baetis Leach, 1815 (Insecta, Ephemeroptera). Jahrgang. 216 str.

NiLLSON, A. (1996). Aquatic insect of North Europe. Apollo Books, Stenstrup. 274 str.

NOGA, T., STANEK-TARKOWSKA, J., PESZEK, Ł., PAJĄCZEK, A. and KOWALSKA, S. (2013): Use of diatoms to asses water quality of anthropogenically modified Matysówka stream. Journal of Ecological Engineering. 14: 1-11.

NORRIS, R.H., BARBOUR, M.T. (2009). Bioassessment of Aquatic Ecosystem, Pollution and Remediation. Elsevier Inc.

PANTLE, R., BUCK , H. (1955): Die biologische Überwachung der Gewässer und die Darstellung der Ergebnisse. Besondere Mittelung und Deutschen Gewässerkundlichen 12:135-143

PANTLE, R., BUCK, H. (1955): Die Biologische Uberwaschung der Gewaser und die darstellung der Ergebnisse Gas und Waserfach 96: 604.

PATRICK, R., PALAVAGE, D. M. (1994): The Value of Species as Indicators of Water Quality. Proceedings of the Academy of Natural Sciences of Philadelphia. 145: 55-92.

PFLEGER, V. (1999). Molluscs. Blitz Editions. Leicester. 216.

PLENKOVIĆ-MORAJ, A., GLIGORA UDOVIĈ, M., KRALJ BOROJEVIĆ, K., TUUTiNIĆ, P. (2009): Fitobentos u: EK-KO projekt Habdija, I., Kerovec, M., Mrakovčić, M., Plenković-Moraj, A., Primc Habdija, B. (2009 a, b i c): Ekološko istraživanje površinskih voda u Hrvatskoj prema kriterijima Okvirne direktive o vodama. PMF, Sveučilište u Zagrebu, Zagreb.

ROUND, F.E., CRAWFORD, R.M., MANN, D.G. (2000). The diatoms, Biology \& morphology of the genera. Cambrige University Press, Cambridge.

SLADAČEK, V. (1979). System of water quality from the biological point of view. Arch. Hydrobiol. Beih. Ergebn. Limnol., 7 (I - II): 1-218.

SLUŽBENE NOVINE FEDERACIJE Bï (2013): Zakon o vodama: Odluka o karakterizaciji površinskih i podzemnih voda, referentnim uvjetima i parametrima za ocjenu stanja voda i monitoringu voda. Sarajevo: Službene novine Federacije $\mathrm{BiH}$, broj 70/06, 10-44. 
TROŽiĆ-BOROVAC, S., HAFNER, D., ŠARAC, M., ŠKRIJELJ, R., ANTUNOVIĆ, M., GAJEVIĆ, M., LONČAREVIĆ, A. (2011): Qualitative and quantitative composition of benthos community in evaluation of water quality of Neretva River at Visici and Zitomislici sites. Zbornik predavanja: V Međunarodna konferencija „Akvakultura i ribarstvo"

VAN DAM, H., MERTENS, A., SINKELDAM, J. (1994): A coded checklist and ecological indicator values of freshwater diatoms from the Netherlands. Netherlands Journal of Aquatic Ecology. 28: 117-133.

WALTON, R. G. (1989): Electrical Conductivity and Total Dissolved Solids-What is Their Precise Relationship Desalination, Volume 72, Issue 3, pp 275-292.

WARINGER, J.,WOLFRAM, G. (1997): Atlas der Österreichischen Kocherfliegenlarven. Facultas - Universitatsverlag, Wien. pp 268.

WARINGER, J., GRAF, W. (2011). Atlas of Central European Trichoptera Larvae, Eric Mauch Verlag, Germany.

WATSON, L., DALLWITZ, M. J. (2005): The families of British non-marine molluscs (slugs, snails and mussels). Version: 10th April 2007.

WEGL, R. (1983): Indeks fur die Limnosaprobitat, Waser und Abwasser. 26, 1-175.

WEGL, R. (1983). Index für die Limnosaprobitaet. -Wasser und Abwasser. Beitraege zur

WEST, W., WEST, G.S. (1905). A Monograph of the British Desmidiaceae. Volume II. Adlard and Son, London.

WEST, W., WEST, G.S. (1908). A Monograph of the British Desmidiaceae. Volume III. Adlard and Son, London.

WOJTAL, A. Z. (2009): The diatoms of Kobylanka stream near Kraków (WyĪyna Krakowsko-częstochowska upland, S Poland). Polish Botanical Journal54: 129330.

ZABELINA, M.M., KiESELEV, I.A., PROŠKinA-LAVRENKO, A.I., ŠUŠEKOVA, V.I. (1951): Opredeljitelj presnovodnih vodoroslej SSSR. Diatomovie Vodorosli. Gosudarstvenoe izdateljstvo Sovjetskaja nauka, Moskva.

ZELINKA, M., MARVAN, P. (1961). Zur Prazisierung der biologischen Klassifikation des Reinheit fliessender Gewässer. Arch. Hydrobiol. 57: 


\section{SAŽETAK}

U ovom radu je predstavljeno istraživanje bentoskih zajednica (fitobentos i krupni beskralješnjaci) na tri postaje na rijeci Neretvi i to; Glavatičevo, Žitomislići i Višići. Rijeka Neretva je najduža i vodom najbogatija rijeka Dinarskog krša. Dužina toka rijeke od izvora do ušća je $240 \mathrm{~km}$. Najvećim dijelom protječe Bosnom i Hercegovinom (90\%), dok samo mali dio (10\%) protječe teritorijem Republike Hrvatske gdje se ulijeva u Jadransko more. Veće pritoke rijeke Neretve su Ljuta, Rakitnica, Bijela, Trešanica, Kraljušnica, Neretvica, Rama, Doljanka, Drežanka, Radobolja, Jasenica, Trebižat (desne pritoke) i Šištica, Baščica, Prenjska rijeka, Šanica, Bijela, Buna, Bregava, Krupa (lijeve pritoke). Krška geologija područja rezultira velikim interakcijama između površinskih i podzemnih voda. Za potrebe ovog istraživanja odabrane se tri postaje rijeke Neretve, od kojih je jedna (Glavatičevo) u gornjem toku rijeke, a Žitomislići i Višići u donjem toku rijeku.

Cilj istraživanja bio je procijeniti ekološki status istraživanih postaja na temelju zajednica fitobentosa i krupnih beskralješnjaka. Ekološki status je odraz kvaliteta, strukture i funkcije vodenih ekosustava površinskih voda. Prema tipologiji površinskih tekućica postaja Glavatičevo pripada podtipu 10a dok postaje Žitomislići i Višići su JIVT (jako izmijenjena vodna tijela).

Istraživanje bentoskih zajednica je provedeno u prosincu 2016 godine uz istovremeno praćenje kemijskih čimbenika vode. Sve istraživane postaje su pokazale veliku brojnost i raznolikost bentoskih svojti iako su uzorci uzimani u zimskoj sezoni. Postaja Glavatičevo prema dobivenim saprobnim indeksima bentoskih zajednica ukazuje na vodu oligosaprobnog stupnja, odnosno vodu neopterećenu organskim tvarima. Postaja Žitomislići ukazuju na vodu oligo-betamezosaprobnog stupnja, odnosno vodu malo opterećenu organskim tvarima. Postaja Višići prema fitobentosu je oligobetamezosaprobna dok je prema makroskopskim beskralješnjacima betamezosaprobna (voda opterećena organskim tvarima).

$\mathrm{Na}$ temelju dobivenih indeksa i mjerenih kemijskih čimbenika vode u skladu s Odlukom o karakterizaciji površinskih $i$ podzemnih voda, referentnim uvjetima $i$ parametrima za ocjenu stanja voda i monitoringu voda (Službene novine $\mathrm{FBiH}$, broj 1/14) maksimalan ekološki potencijal zabilježen je za postaje Žitomislići i Višići dok je za postaju Glavatičevo zabilježeno visoko ekološko stanje.

Corresponding author: Anita Dedić, University of Mostar, Faculty of Science and Education, Rodoč bb, Mostar, E-mail: anita.dedic@fpmoz.sum.ba 